\title{
STATE AIDS AND THE CONSEQUENCES OF THEIR ILLEGALITY UNDER EC LAW
}

\author{
K. Paul E. Lasok*
}

\section{Abstract}

The prohibition of State aids in the EC Treaty applies where competition is distorted by benefits that take the form either of the giving of State resources to one or more undertakings or of the State abstaining from collecting, from one or more undertakings, resources that the State would otherwise be entitled to collect from them. Although State aids are defined in very broad terms, the concept of a State aid does not extend to: State action that does not involve a disposal of State resources in either a positive sense (in the form of a grant of State resources) or in a negative sense (in the form of the State refraining from collecting resources from an undertaking); and State action that is indistinguishable from the decisions of private sector commercial undertakings. If the grant of State aid is prohibited, it must be recovered from the recipient of the aid and few defences to recovery are available.

\section{Introduction}

Article $87(1)$ of the EC Treaty (ex 92(1)) provides: "Save as otherwise provided in this Treaty, any aid granted by a Member State or through State resources in any form whatsoever which distorts or threatens to distort competition by favouring certain undertakings or the production of certain goods shall, in so far as it affects trade between Member States, be incompatible with the common market".

The Treaty sets out a complicated regime for putting into effect the prohibition on State aids that is implicit in Article 87(1). The Treaty draws a distinction between "existing" and "new" State aids. The Commission is entrusted with the function of deciding whether or not a State aid is compatible with the common market. In the case of "existing" State aids, it is only when the

*Dr., Monckton Chambers, London. 
Commission reaches a decision that is unfavourable to the aid in question that legal consequences flow upon which private persons may rely. Until then, the aid is not unlawful. The position of "new" State aids is somewhat different. Such aids have to be notified to the Commission before they are introduced. If they are introduced without notification, they are automatically unlawful; and private persons may rely upon their illegality before national courts. If they are notified to the Commission before their introduction, no adverse legal consequences for the State aid flows unless and until the Commission reaches an adverse decision. ${ }^{1}$ Thus, upon notification to the Commission, a "new" State aid becomes an "existing" one.

\section{What is a State aid?}

To be caught by the Treaty, a State aid must possess the following features:

(a) it must be an "aid";

(b) it must be "granted by a Member State or through State resources";

(c) it must "distort or threaten to distort competition by favouring certain undertakings or the production of certain goods"; and

(d) it must affect trade between Member States.

Although the wording of Article 87(1) permits those features to be separated from one another, there is in practice a close relationship between them. For example, the implication from the use of the word "aid" is that a State aid is something that is advantageous to the recipient. The same emerges from the third feature of a State aid, that it "distorts or threatens to distort competition by favouring certain undertakings or the production of certain goods" (emphasis added). As a result, it is difficult to conduct a discussion of what is a State aid by disaggregating the different parts of Article 87(1) and examining them individually and in isolation from the other parts. Nonetheless, that is what will be attempted here.

The main emphasis will be placed on more recent cases decided by the Court of Justice of the European Communities ("the ECJ") and the Court of First Instance ("the CFI"); but there will be some mention of older cases.

\section{"Aid"}

Article $87(1)$ refers to "any aid" and later, in connexion with the second feature identified above (the grant of the aid by a Member State or through State resources), employs the phrase "in any form whatsoever". The obvious intention of the Treaty is to cast a broad net and, more particularly, to bring within the concept of a State aid caught by the Treaty anything that has all the features of a State aid irrespective of it "form": substance is everything and the appearance or designation given to something is not important. In reality, 
however, despite the apparent breadth of the wording used, not everything that can be said to have the features of a State aid is a State aid.

A fairly typical description of the concept of an aid ${ }^{2}$ is that given by the ECJ in Case C-200/97 Ecotrade v Altiforni e Ferriere di Servola" "...the concept of aid is wider than that of a subsidy because it embraces not only positive benefits, such as subsidies themselves, but also measures which, in various forms, mitigate the charges which are normally included in the budget of an undertaking and which, without therefore being subsidies in the strict meaning of the word, are similar in character and have the same effect..."” The ECJ went on to hold: "..the expression "aid"...necessarily implies advantages granted directly or indirectly through State resources or constituting an additional charge for the State or for bodies designated or established by the State for that purpose...". Although those statements were made in the context of the ECSC Treaty, the judgment in fact emphasises the conceptual similarity between aids under that Treaty and aids under the EC Treaty.

Ecotrade indicates that a State aid is an advantage and also that the advantage can take the form either of a "positive benefit" or a "mitigation" of the charges that an undertaking would normally have to bear. At first sight, there is no distinction between the two: when charges are mitigated, surely the undertaking receives a positive benefit? In a later case, Case C-251/97 France $v$ Commission, the ECJ dropped the reference to "positive benefit" and simply said that the concept of an aid encompasses measures that mitigate an undertaking's charges. However, it would seem that that dictum was intended to reflect the facts of that particular case (which concerned a measures reducing social charges imposed on certain undertakings) rather than to introduce a definitive reformulation of the concept of an aid.

The distinction set out in the case law appears to lie in the fact that, when an undertaking receives a positive benefit, the State (or some State body) is taking some positive action to give that undertaking an advantage. The advantage can take all kinds of forms: a straightforward payment of money (as in the case of a subsidy); investment in the capital of an undertaking'; the giving of a guarantee; purchasing goods or services from the favoured undertaking in the absence of any, or any sufficient, demand for them or at an overvalue ${ }^{6}$. In all those cases, the State (or a State body) is transferring State resources to the undertaking in question.

On the other hand, when an undertaking's charges are mitigated, it is being relieved of all or part of an obligation itself to pay money or allocate its own resources in some other way for the benefit of someone else. For example: a 
reduction in social charges to be paid by undertakings ${ }^{7}$; a tax concession or tax exemption that reduces the undertaking's liability towards the State ${ }^{8}$.

While it is convenient to analyse State aid as comprising either the transfer of resources to the favoured undertaking or relieving the favoured undertaking from the obligation to dispose of its own resources (to a greater or lesser extent), the classifications arising from that analysis should not be regarded in too rigid a light. For example, where the advantage consists of the State (or a State body) making available an asset or providing services free of charge or at an undervalue, the aid can be characterised either as the conferral of a positive benefit or as a mitigation of the charges that the favoured undertaking would otherwise have to bear, depending upon one's point of view. On another view, such a situation can quite properly be regarded as an example of an aid that is both a positive benefit and a mitigation of charges.

A more important point arising from the analysis of aids into positive benefits and the mitigation of charges also emerges from Ecotrade: how can the inclusion of action mitigating charges within the concept of an aid be reconciled with the emphasis apparently placed by the ECJ on the need for the aid to involve the employment of State resources of an "additional charge" for the State? That problem will be discussed in the context of the second requirement of a State aid, that it be granted by the State or through State resources. Before moving on to that requirement, a further aspect of the concept of an aid requires consideration.

It has been stated on a number of occasions that "the aim of Article 92 [now 87] is to prevent trade between Member States from being affected by advantages given by the public authorities which, in various forms, distort or threaten to distort competition by favouring certain undertakings or the production of certain goods" 10 . In one case, the ECJ said: "in order to determine whether a State measure constitutes aid, it is necessary to establish whether the recipient undertaking receives an economic advantage which it would not have obtained under normal market conditions"11. The use in Article 87(1) of the word "aid" and the feature possessed by a State aid of distorting competition by "favouring" certain undertakings or the production of certain goods" all support the conclusion that for something to be an aid it must be an advantage. All the cases are cases involving advantages of various sorts. At first sight at least, the conclusion is obvious and common sense. There may be some dispute as to whether or not a particular measure is, in a particular set of circumstances, an "advantage", particularly "an advantage which it [the favoured undertaking] would not have obtained under normal market conditions" (as to which see further below). There cannot (it would seem) be any dispute about the fact that an aid must be an advantage ${ }^{12}$. 
But is that correct? Or, to put it another way, could the imposition of a disadvantage constitute a State aid?

Suppose this situation: a Member State has, in a part of its territory cursed by a high level of unemployment, an undertaking in difficulties which is also a major employer in that area; if the undertaking goes out of business, the level of unemployment will soar to politically unacceptable levels; the State (in the form either of central government or, perhaps more realistically, local or regional govemment) wishes to do something to assist the undertaking. Financial support is impossible either because the money is not available or because it would be too obvious an infringement of the EC Treaty. The relevant State authority therefore secretly employs desperadoes to sabotage a competing undertaking in a well-off part of the State, in which the repercussions of the closure of the competitor will, in relative terms, pass unnoticed. The desperadoes blow up the competitor's factory. Aided by the disappearance of its nearest competitor, the undertaking in difficulties recovers.

Put in more abstract terms, the example given above is that of a situation in which the undertaking benefiting from State action receives no direct benefit or advantage or aid from the State at all. There is no positive benefit in the form of the direction of State resources towards the favoured undertaking. There is no mitigation of the charges borne by that undertaking. Instead, the "aid" takes the form of the imposition of a disadvantage on a competing undertaking. The economic effect of the disadvantage may well be exactly the same as if the State had given the undertaking in question a financial subsidy enabling it to undercut its competitor and drive it out of business.

In virtually all cases, it is not necessary to ask the question whether or not a State "aid" can be a disadvantage imposed on one undertaking rather than an advantage conferred on another: all cases of "aid" in the generally accepted sense (namely, that of the conferment of an advantage on someone, whether it be a positive benefit or the mitigation of a charge) necessarily have the concomitant element of a disadvantage suffered by a competitor or by competing goods. Attention focuses on both the advantage and the disadvantage: the former is the "aid", the latter is the competitive consequence that engages the operation of the State aid rules in the Treaty. Therefore, it is in fact incorrect to analyse the disadvantage suffered by a competitor or by competing goods as "the aid": the disadvantage is the consequence of the aid, not the aid itself.

That, however, is the correct analysis in all cases in which the aid takes a traditional form. For example, where the aid is a financial benefit, such as a subsidy, granted to a particular undertaking, it would be absurd to characterise the aid as the disadvantage imposed on other undertakings who were not granted 
the benefit. The absurdity can be seen from the legal consequences of so characterising the aid. When a State aid is granted unlawfully, it must be clawed back from the recipient ${ }^{13}$. If the aid were characterised as the disadvantage imposed on the disfavoured undertakings, how could that "aid" be clawed back? The financial benefit could, of course, be extended to all the undertakings that did not receive it; but that would involve the grant of more aid, not the removal of the aid ${ }^{14}$. That factor is particularly important because the State aid rules are essentially concerned with the effect of aid on inter-State trade. if one undertaking in a Member State is benefiting from a State aid that affects interState trade and competition, that is bad enough. It is an aggravation of - not a solution to - the problem if more undertakings in that State are given the aid.

What, however, of the situation in which no benefit is conferred on the favoured undertaking (or the favoured goods) other than that consequential upon the disadvantage imposed on a competitor (or competing goods)?

As the case law currently stands, it would seem that, unless the imposition of a disadvantage involves the employment of State resources, it will not constitute a State aid: the question whether or not the disadvantage involves a mitigation of the charges borne by the favoured undertaking does not need to be considered because, ex hypothesi, the kind of situation here under consideration does not produce any such advantage for the favoured undertaking. However, some caution should perhaps be exercised before regarding that conclusion as definitive because the case law has not really addressed this problem.

The other aspect of the concept of an aid as an advantage that needs to be considered here is encompassed in the dictum quoted above, that "in order to determine whether a State measure constitutes aid, it is necessary to establish whether the recipient undertaking receives an economic advantage which it would not have obtained under normal market conditions".

There is a body of case law, traceable back to the Advocate General's Opinions in Case 84/82 Germany v Commission ${ }^{15}$ and Cases 296 and 318/82 Netherlands \& Leeuwarder Papierenfabrik v Commission ${ }^{16}$, indicating that an advantage accorded by the State will not be classified as a State aid if, in short, it is no different from what the favoured undertaking could have got from private sector sources under normal market conditions. That principle, often referred to as "the private investor test", originated in cases involving investments in the capital of an undertaking or the grant of loans to an undertaking, where the transaction was in terms of its form and appearance identical to a standard commercial transaction. The ECJ was not prepared to accept that the Member States, or State bodies, were prevented by the Treaty from entering into ordinary 
commercial transactions of that sort. On the other hand, it did take the view that such transactions could be objectionable if a private sector investor (or lender, or whatever) would not have entered into the transaction at all (usually because of the perilous state of the recipient undertaking) or if the terms available from the private sector would have been different (that is, less favourable). In either event, the recipient undertaking would be getting from the State something that it would not otherwise have got, and it was therefore legitimate to conclude that a State aid was involved.

When applying the private investor test, it is necessary to take a private sector comparison that is as close as possible to the transaction effected by the State (or a State body) that is suspected of being a State aid. It is not necessarily the case that the hypothetical private investor would seek a profit in the short term because private investors may well be guided by the prospect of profitability in the longer term; but the general principle of the test is to determine whether or not the transaction would or could have been entered into with a private sector counterparty envisaging making a return on the transaction (or at least minimising losses ${ }^{17}$ and leaving aside any consideration of the social, regional, sectoral or other policy considerations that typically motivate the State (or State bodies) ${ }^{18}$

Finally, an advantage granted by the State (or a State body) is not excused from being a State aid merely because it serves some particular purpose or policy. In fact, one of the early definitions of a State aid was that it (or rather Article 87(1)) encompassed "decisions of Member States by which the latter, in pursuit of their own economic and social objectives, give by unilateral and autonomous decisions, undertakings or other persons resources or procure for them advantages intended to encourage the attainment of the economic or social objectives sought" 19 . As a result, it has on occasion been stated, as did the CFI in Case T-14/96 Bretagne Angleterre Irlande $v$ Commission ${ }^{20}$, that "the cultural and social aims pursued by the Spanish authorities play no part in the characterisation of the 1995 agreement in the light of Article 92(1) of the Treaty [now 87]. According to settled case-law, Article 92(1) makes no distinction according to the causes or aims of the aid in question, but defines it in relation to its effects (...). Those aims may nonetheless be taken into account by the Commission when, in exercising its power of constant review under Article 93 of the Treaty [now 88], it rules on the compatibility with the common market of a measure already categorised as State aid and verifies whether that measure falls within the derogations provided for by Article 92(2) and (3) [now 87(2) and (3)] (...)".

On the other hand, it does not follow that all policy justifications for a particular measure must be ignored. In Cases 67, 68 and 70/85 Van der Kooy 
$v$ Commission ${ }^{21}$, the ECJ accepted that a preferential tariff applicable to a particular class of undertakings might not be an aid "if it were demonstrated that the...tariff was, in the context of the market in question, objectively justified by economic reasons such as the need to resist competition on the same market from other sources of energy the price of which was competitive". In Ecotrade ${ }^{22}$, the ECJ rejected the argument that a system of special administration for insolvent undertakings gave rise to a State aid merely because the application of the system would produce a loss of tax revenue for the State (since insolvent undertakings to which the system applied would be sheltered from claims and the running of interest on their debts would be suspended). The ECJ regarded that consequence as "an inherent feature of any statutory system laying down a framework for relations between an insolvent undertaking and the general body of creditors...".

In Case C-251/97 France v Commission ${ }^{23}$, France sought to justify a reduction of social charges affecting certain undertakings on the ground that it was a corrective measure designed to compensate for certain exceptional costs that the undertakings had incurred as a result of various collective agreements made between employers' organisations and trade unions. The ECJ rejected the argument that the reductions were not a State aid; but it did not do so on the ground that the French government's analysis of the situation was completely irrelevant. It did so because the system of collective agreements was intended to (and apparently did) enhance competitiveness. Accordingly, it was not possible simply to extract the negative aspects of the situation (in the form of higher social charges) and use them to justify the alleged State aid, simply ignoring the positive aspects.

Thus, despite dicta in the case law to the contrary, Article 87 [ex 92] does not cover all measures which have an effect equivalent to a State aid; to extend the scope of the treaty in that way would entail an enquiry on the basis of the Treaty alone into the entire social and economic life of a Member State, which one Advocate General has warned against ${ }^{24}$.

\section{"Granted by a Member State or through State resources"}

In Cases C-52/97, C-53/97 and C-54/97 Viscido $v$ Ente Poste Italiano ${ }^{25}$, the ECJ was confronted with a case in which the alleged State aid was a legal provision relieving a particular undertaking from a generally applicable obligation imposed on employers to recruit staff under employment contracts of indeterminate duration, as opposed to fixed term contracts. The national court had considered that the legislation gave the favoured undertaking a flexibility not available to other undertakings operating in the same sector. Nonetheless, 
the ECJ did not consider that the advantage was a State aid. It held that the wording of Article $87(1)$ "does not signify that all advantages granted by a State, whether financed through State resources or not, constitute aid but is intended merely to bring within that definition both advantages which are granted directly by the State and those granted by a public or private body designated or established by the State". The legislation at issue was not a State aid because it "does not involve any direct or indirect transfer of State resources to" the beneficiary.

A direct transfer is simply a payment. Indirect transfers encompass situations where the State forgoes a payment to which it would otherwise be entitled, such as where it creates a tax exemption and thereby accepts a drop in tax revenue but does not employ its resources for the benefit of the favoured undertaking in any positive way ${ }^{26}$. In order to be a State aid, an advantage must therefore involve some additional burden for the State. In Ecotrade ${ }^{27}$, the ECJ suggested that, if the advantage does not involve some additional burden, by comparison with the situation that would otherwise prevail, it may not be a State aid. it is not at present clear how far that remark can be taken.

\section{Effect on competition and on trade between Member States}

The final elements of a State aid caught by the EC Treaty are common to the other competition rules in the Treaty: an effect on competition and on trade between Member States. The application of those requirements in the State aid context is very little different from their application in the context of Articles 81 and 82 of the EC Treaty (ex 85 and 86). Nonetheless, it is worth noting that, in Case C-156/98 Germany v Commission ${ }^{28}$, Advocate General Saggio considered that the primary effect of the aid was to make investment in the undertakings benefiting from the aid more attractive and that that meant that there was an effect on inter-State trade because, in principle, investment in every undertaking established in another Member State that did not benefit from the aid was possible under less favourable conditions ${ }^{29}$.

The principal areas of difference - or of possible difference - between the State aid rules and Articles 81 and 82 lie in (i) the express requirement set out in Article 87(1) of the Treaty that an aid shall distort or threaten to distort competition "by favouring certain undertakings or the production of certain goods" (often referred to as "selectivity"); and (ii) the question whether or not the State aid rules contain a de minimis rule, as in the case of Articles 81 and 82.

Selectivity is one of the defining features of an aid ${ }^{30}$. In Ecotrade, where the ECJ did not object to a general system for dealing with insolvent undertakings, it did object to certain aspects of the system which suggested that it was intended 
to apply selectively to certain types of undertaking. Similarly, in Case C-156/98 Germany $v$ Commission $^{31}$, a tax concession made available to a defined group of undertakings was considered to be selective even though the number of beneficiaries was indeterminate.

In relation to the de minimis rule, different views have been expressed as to whether or not it applies in the context of State aid. For example, in Case C-142/87 Belgium v Commission ${ }^{32}$, the Advocate General considered that the effect had to be significant. The judgment is often cited as authority for the proposition that there is no de minimis rule but in fact it merely dismissed the reliance placed by Belgium on a relative test of significance (based on percentages). More precisely, Belgium had invoked the Commission's notice on agreements of minor importance which, as then worded, set out an absolute test of significance based on turnover and a relative test based on market share. The ECJ did not consider that picking out the relatively small size of the aid or the relatively small size of the recipient was sufficient to exclude the possibility of there being an effect on intra-Community trade. However, it did not hold that there was no de minimis rule at all.

More recently, in the Neue Maxhutte Stahlwerke case ${ }^{33}$, the CFI pointed out that the ECSC Treaty contains no requirement that a State aid distorts or threatens to distort competition. The CFI concluded from that that the ECSC Treaty did not embody a de minimis rule. A week after that case was decided, the CFI decided Case T-14/96 Bretagne Angleterre Irlande $v$ Commission ${ }^{34}$. There, it repeated the dictum in Belgium $v$ Commission, saying that the relative smallness of the amount of aid or the size of the recipient does not "as such" exclude the possibility of an effect on trade; and it went on to point out (again citing earlier cases) that "the capacity of an aid to strengthen the recipient's competitive position is assessed by reference to the advantage given to the recipient, and it is unnecessary to take account of the operating results of its competitors". In Case C-156/98 Germany v Commission ${ }^{35}$, Germany invoked the de minimis rule, an expression of which it claimed to find in the Commission's 1996 notice on de minimis State aids ${ }^{36}$. The Advocate General dismissed the argument on the facts but did not assert that there was no de minimis rule at all ${ }^{37}$.

In short, the cases so far have been concerned with rejecting particular methods of assessing the effect of an aid rather than with the question whether or not there is a de minimis rule. It would therefore appear that the existence of a de minimis rule in the State aid rules of the EC Treaty remains an open question. 


\section{The consequences of illegality}

Where new aid has been put into effect without having first been notified to the Commission, the Commission may require the State concerned to suspend further grant of the aid until the Commission has ruled on its compatibility with the common market; and the Commission may also require the State concerned to recover aid that has already been granted (such recovery being "provisional" only) ${ }^{38}$. The Commission may order (provisional) recovery only if: (i) according to established practice, there are no doubts about the aid character of the measure concerned; (ii) there is urgency to act; and (iii) there is a serious risk of substantial and irreparable damage to a competitor ${ }^{39}$. Recovery will be effected in accordance with the domestic procedures of the Member State concerned ${ }^{40}$. However, a broader right to secure recovery exists under the Treaty that can be invoked by private persons (not the Commission) in proceedings before national courts ${ }^{41}$.

Again, in the case of new aid granted without first having been notified to the Commission, when the Commission concludes that such aid is incompatible with the common market (and not simply granted in breach of the requirement of prior notification), it must order the (definitive) recovery of aid already paid out unless such an order would be incompatible with a general principle of Community law ${ }^{42}$. Recovery is effected in accordance with domestic procedures ${ }^{43}$ and may not be ordered more than 10 years after the original grant of the aid ${ }^{44}$. The same applies where an existing aid is misused, recovery operating from the point in time at which the aid began to be misused (subject to the same limitation period) $)^{45}$. On the other hand, where an existing aid scheme is found by the Commission to be incompatible (or no longer compatible) with the common market, the Commission must recommend appropriate measures, which may include the substantive amendment or even the complete abolition, of the aid scheme ${ }^{46}$. Recovery of aid already paid out does not feature as part of the measures that the Commission may recommend. That is because, until the Commission has concluded that the aid scheme is incompatible with the common market, sums paid out as aid have been paid and received legitimately.

The proportionate amount of aid to be recovered is the entire amount $t^{47}$. However, a recipient of aid subject to recovery may be entitled to rely upon the principle of the protection of legitimate expectations by way of defence to the recovery of the aid. The extent of that defence is severely limited because it is assumed that a diligent person will make proper enquiry before receiving a State aid in order to ascertain that it has been granted in accordance with Community law. Nonetheless, there may be exceptional circumstances in which the defence will be available ${ }^{48}$. 
In addition to the recovery of illegally granted aid, a further consequence is that the State granting the aid may be liable in damages for the loss caused to competitors of the beneficiaries of the aid as a result of the illegal grant of the aid. So far, no successful actions for damages appear to have been brought. Where the competitors injured by the grant of the aid are in a Member State other than that in which the beneficiaries of the illegal aid are located, one of the main stumbling blocks to the recovery of damages has been thought to be the problem of causation. That problem was particularly acute in cases where the currencies of the States concerned did not operate at fixed parities during the relevant period. That difficulty, at least, no longer applies as between States within the Euro zone.

\section{Conclusions}

Unlike the prohibition of quantitative restrictions on trade between Member States - which has been largely successful in eliminating such barriers to trade, the prohibition of State aids remains an important element in the machinery of the common market. Despite the long standing case law on what is a State aid and which kinds of State aid are incompatible with the common market, the grant of State aids is a perennial problem, as can be seen from the relatively high level of State aids cases decided by the ECJ and the CFI over the last few years. Hence, the rules regarding State aids and the consequences of the grant of unlawful aid remain of continuing importance and interest.

\section{Endnotes}

${ }^{1}$ The procedure followed by the Commission is now to be found in Council Regulation No. 659/1999 (OJ 1999 No. L83/1).

${ }^{2}$ For some of the early definitions, see K.P.E.Lasok, State Aids and Remedies, [1986] European Competition Law Review 53 at 54-60.

${ }^{3}$ [1998] ECR I-7907. paragraphs 34-35.

${ }^{4} 5$ October 1999, paragraph 35.

${ }^{5}$ E.g. Case C-142/87 Belgium v Commission [1990] ECR I-959, paragraphs 25-26.

${ }^{6}$ Cf. Case T-14/96 Bretagne Angleterre Irlande v Commission [1999] ECR I-139, paragraphs 71-76.

${ }^{7}$ E.g. Case 173/73 Italy v Commission [1974] ECR 709 (family allowances); Case C251/97 France $v$ Commission (above).

${ }^{8}$ E.g. Case C-387/92 Banco de Credito Industrial v Ayuntamiento de Valencia [1994] ECR I-887, paragraphs 13-14; Case T-106/95 FFSA v Commission [1997] ECR II229. 
${ }^{9}$ E.g. Cases 67, 68 and 70/85 Kwekerij Gebroeders Van der Kooy v Commission [1988] ECR 219.

${ }^{10}$ Case T-14/96 Bretagne Angleterre Irlande v Commission [1999] ECR II-139, paragraph 71, emphasis added.

${ }^{11}$ Case C-39/94 SFEI v La Poste [1996] ECR I-3547, paragraph 60.

${ }^{12}$ See, in that connexion, paragraph 29 of Advocate General Saggio's Opinion of 27 January 2000 in Case C-156/98 Germany v Commission, where the analysis of the alleged aid was couched entirely in terms of the conferral of an advantage.

${ }^{13}$ E.g. SFEI v La Poste (above), paragraph 68 (in the context of what is now Article $88(3))$.

${ }^{14}$ Lest it be thought that the problem outlined above is somewhat unrealistic, it should be noted that, in the United Kingdom, an attack was launched on the introduction of a standard and a higher rate of Insurance Premium Tax precisely on the ground that the disadvantage suffered by the payers of the higher rate was a State aid. The Court of Appeal concluded that the aid was the benefit conferred on the payers of the (lower) standard rate: see $R v$ Commissioners of Customs and Excise, ex parte Lunn Poly Ltd. and another [1999] STC 350 at 362j and 365c. However, other litigants are continuing to pursue claims based on the theory that the imposition of a financial disadvantage can be a State aid.

15 [1984] ECR 1451.

16 [1985] ECR 809.

${ }^{17}$ E.g. case C-480/98 Spain v Commission, Opinion of Advocate General Mischo, paragraph 35 . The desire to minimise losses may emerge when it becomes clear that the beneficiary of the aid is failing and the question arises when (if at all) the grantor should seek to recover any part of the aid that the recipient is able to pay back (ibid., paragraph 43).

${ }^{18}$ For a recent example of consideration of the test, see Cases T-129/95, T-2/96 and T-97/96 Neue Maxhutte Stahlwerke and others v Commission [1999] ECR II-17, paragraphs 104-140.

${ }^{19}$ Case 61/79 Amministrazione delle Finanze dello Stato v Denkavit [1980] ECR 1205 , paragraph 31.

${ }^{20}$ Above, see paragraph 81.

21 [1988] ECR 219, paragraph 30.

22 Above, see paragraph 36.

235 October 1999.

${ }^{24}$ Advocate General Jacobs in the Viscido case (note 22 below), paragraph 16 of his Opinion.

25 [1998] ECR I-2629, paragraphs 12-16. 
${ }^{26}$ Cf. the tax concession at issue in Case C-156/98 Germany v Commission (Opinion of Advocate General Saggio, paragraph30).

27 Above, paragraph 43.

28 Judgment pending.

${ }^{29}$ Paragraphs 29 and 31 of his Opinion.

30 The Ecotrade case (above), paragraph 40 (see further paragraphs 37-39).

31 Judgment pending (see the Opinion of Advocate General Saggio, paragraph 31).

32 [1990] ECR I-959 at 1001 (the Advocate General's Opinion) and paragraph 43 of the judgment.

${ }^{33}$ Above, see paragraph 147.

${ }^{34}$ Above, see paragraphs 77-78.

${ }^{35}$ Above.

${ }^{36}$ OJ 1996 No. C68/9.

${ }^{37}$ See paragraph 33 of his Opinion.

38 Regulation No. 659/1999, Article 11. That provision fills a gap in the Treaty provisions. Under the Treaty, the Commission could only order future payments to be suspended and could not order the recovery of payments that had already been made: see Case C-39/94 SFEI and others v Commission [1996] ECR I-3547, paragraph 45. ${ }^{39}$ Ibid., Article 11(2).

${ }^{40}$ Articles 11(2), second sentence, and 14(3).

${ }^{41}$ See, for example, the SFEI case, above.

42 Regulation No. 659/1999, Article 14(1).

${ }^{43}$ Ibid., Article 14(3).

${ }^{44}$ Article 15(1).

45 Article 16.

${ }^{46}$ Article 18.

${ }^{47}$ Cf. Case C-142/87 Belgium v Commission [1990] ECR I-959, paragraph 66. ${ }^{48}$ Case C-5/89 Commission v Germany [1990] ECR I-3437, paragraphs 14 and 16. 